ENTREPRENEURSHIP AND SUSTAINABILITY ISSUES

ISSN 2345-0282 (online) http://jssidoi.org/jesi/

2020 Volume 8 Number 2 (December)

http://doi.org/10.9770/jesi.2020.8.2(23)
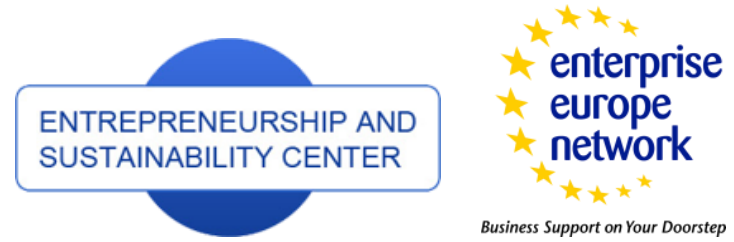

Business Support on Your Doorstep
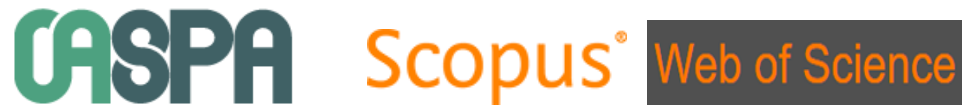

http://jssidoi.org/esc/home

\title{
Clarivate \\ Analytics \\ EVALUATION OF THE EFFECTIVENESS OF INSOLVENCY FRAMEWORKS: DOES THE SMALL BUSINESS PERSPECTIVE MATTER?
}

\author{
Salvija Mulevičienė \\ Mykolas Romeris Law School, Mykolas Romeris University, Ateities st. 20, 08303 Vilnius, Lithuania \\ E-mail: salvija@mruni.eu
}

Received 15 July 2020; accepted 25 August 2020; published 30 December 2020

\begin{abstract}
The exit of business from the market based on the rules of sound insolvency law is a necessary condition for economic growth. Effective insolvency frameworks encourage entrepreneurship. Currently insolvency laws in many countries are designed with the complexity of medium sized or even large companies in mind, but businesses are very heterogeneous in their characteristics and performance. This paper highlights the importance of taking into account the perspective of individual entrepreneurs, micro, and small enterprises (IMSE) when designing insolvency frameworks. It summarizes the theoretical and empirical literature on the objectives of insolvency law, discusses the unique challenges encountered by IMSEs when facing insolvency, and analyses international standards with the aim of discerning whether the existent instruments offer adequate guidance for policy reforms when designing effective insolvency frameworks and taking into account the needs of small businesses. The aim of this paper is to analyse the specific challenges of insolvent small business: individual entrepreneurs, micro, and small enterprises, and to consider whether existing international standards provide policy makers with sound guidelines and directions for the development of modern national insolvency frameworks that adequately address the needs of small businesses.
\end{abstract}

Keywords: insolvency law; entrepreneurship; effectiveness of insolvency framework; micro enterprises; small enterprises; small business

Reference to this paper should be made as follows: Mulevičienè, S. 2020. Evaluation of the effectiveness of insolvency frameworks: does the small business perspective matter? Entrepreneurship and Sustainability Issues, 8(2), 383-398. http://doi.org/10.9770/jesi.2020.8.2(23)

JEL Classifications: K20, L31

Additional disciplines: law, economy, business 


\section{ENTREPRENEURSHIP AND SUSTAINABILITY ISSUES}

ISSN 2345-0282 (online) http://jssidoi.org/jesi/

2020 Volume 8 Number 2 (December)

http://doi.org/10.9770/jesi.2020.8.2(23)

\section{Introduction}

Entrepreneurship and self-employment are recognised as the key enablers of smart, sustainable, and inclusive growth (United Nations, 2017; European Commission, 2012). Growth and productivity need to be supported by competitive and efficient markets, and structural reforms that remove bottlenecks in the business environment (European Commission, 2019). A conducive business environment, including institutional and regulatory settings, is essential to incentivise risk-taking and experimentation by entrepreneurs, and foster business growth potential (OECD, 2018). Evidence suggests that the exit of firms from the market based on the sound insolvency law rules is a necessary condition for economic growth, and effective insolvency frameworks may in fact encourage greater entrepreneurial activity and new firm creation (Cirmizi, Klapper, \& Uttamchandani, 2010; McGowan \& Andrews, 2016). At the level of European Union (EU) policy, effective insolvency frameworks are also singled out as one of the most important determinants of a Member State's business environment in that regard (European Commission, 2019). At the scientific level, it has long been recognised that when innovative activity in an industry increases, firms' overall survival rates often decrease, but those that do survive tend to be stronger (Nickell, 1996; Klapper, Laeven, \& Rajan, 2006; Cirmizi et al., 2010). As highlighted in the recent report of the Organisation for Economic Co-operation and Development (OECD) which introduces the new indicators on the measurement of the effectiveness of insolvency regimes, in the long-run productivity growth is sustained, inter alia, by firms' experimentation with new ideas and the reallocation of scarce resources to their most productive uses. So reviving productivity growth will, in part, depend on policies that effectively facilitate the exit or restructuring of weak business (OECD, 2018a) - in other words, on effective insolvency frameworks.

Furthermore, insolvency frameworks have an important secondary effect on entrepreneurship, as many entrepreneurs do not start a company because of their fear of the consequences of business failure. According to the results of the Flash Eurobarometer Survey No. 354 "Entrepreneurship in the EU and Beyond"-which covered the 27 countries currently comprising the EU as well as 13 countries from outside the EU-the fear of bankruptcy and the fear of losing their own home are indicated as the main fears held by the majority of the respondents in starting their own business in Europe (EU Directorate-General for Communication, 2015).

Additionally, insolvency frameworks are of increasing importance not merely in their own right but also because insolvency impinges on a host of other sectors such as the fields of employment, tort, environmental, pension, and banking law. It is essential, therefore, that the development of insolvency law proceeds with a sense of purpose. If lacking a sense of direction, this area of law is liable to be marked by inconsistencies of reasoning and failures of policy (Finch, 1997).

Currently, despite wide-ranging insolvency reforms in many countries, the complexity of regulation, high compliance costs, and ineffective insolvency regimes remain major obstacles to entrepreneurial activity. Upon first glance at this huge array of comparative information, it is clear that the design of each insolvency regime varies significantly across countries (McGowan \& Andrews, 2018). However, one general feature can be distinguished: in many countries insolvency laws are designed with the complexity and sophistication of medium sized or even large companies in mind (The World Bank, 2017; Mokal et al., 2018), but the businesses are very heterogeneous in their characteristics and performance. Under the same label of business fall individual entrepreneurs, micro enterprises, and small enterprises (together - IMSE), which are vastly different from medium sized companies and the large international firms in relation to employees, access to finances, professional management services, and liability.

Despite the diversity and complexity of the characteristics of small business, until now there has been only little academic research on the effect of insolvency frameworks on IMSEs. But there is a growing awareness that the treatment of small business in insolvency is one of major bottlenecks of the insolvency frameworks (Mokal et al., 2018; Madaus, 2017; Bergthaler, Kang, Liu, \& Monaghan, 2015). At the EU level, the EU Entrepreneurship 2020 


\section{ENTREPRENEURSHIP AND SUSTAINABILITY ISSUES}

ISSN 2345-0282 (online) http://jssidoi.org/jesi/

2020 Volume 8 Number 2 (December)

http://doi.org/10.9770/jesi.2020.8.2(23)

Action Plan also states that the support measures for small business remain unbalanced, with a substantial number of EU Member States still neglecting to take into account the characteristics of small businesses, in particular micro-businesses, when designing legislation, or not facilitating a second chance for honest bankrupt entrepreneurs (European Commission, 2012). Therefore, national policy makers are advised to assess national insolvency laws applicable to small businesses in the light of good practices (e.g., European Commission, 2000), and when initiating reforms to look for guidance and direction from international expert organisations and best practices examples from other countries.

Only recently are some efforts being seen at the international, regional, and national levels to discuss in more detail the need to find solutions tailored to the specific needs of financially distressed IMSEs, aiming at allowing deserving IMSEs to restart entrepreneurial activities in the light of the broad impact of IMSEs insolvency on job preservation, the supply chain, entrepreneurship, and the economic and social welfare of society (e.g., UNCITRAL, 2020; OECD, 2018a). These discussions started to evolve from the initial question of whether the standards for effective business insolvency, as developed by influential international organisations, are appropriate when applied to a wider group of small and medium sized enterprises, and specifically to the question of whether they are suitable for IMSEs at all taking into account their specific nature. In a recent report, researchers from the United Nations Commission on International Trade Law (UNCITRAL) stated that standard business insolvency processes, where they are costly, complex, lengthy, and procedurally rigid, may be unavailable, prohibitive, or unsuitable for IMSEs. Burdened by unresolved financial difficulties and old debt, IMSEs may be discouraged from taking new risks, may become trapped in a cycle of debt, or may be driven to the informal sector of the economy (UNCITRAL, 2020).

Therefore, the aim of this paper is to analyse the specific challenges of insolvent small business: individual entrepreneurs, micro, and small enterprises, and to find out whether existing international standards provide the policy makers with sound guidelines and direction for the development of modern national insolvency frameworks that adequately address the needs of small businesses.

In order to achieve this aim the following objectives are set:

1) to determine the specific features relevant from the perspective of insolvency law that distinguish IMSEs from other forms of business, and therefore need to be addressed when designing effective insolvency frameworks;

2) to analyse the sufficiency of instruments and good practice guides that address the needs of small businesses and are aimed at supporting governments in designing and implementing effective insolvency policies in that regard.

This paper is an effort to contribute to the emerging scientific discussion on the research question of whether an effective insolvency framework should, and if so - how, specifically address the needs of IMSEs in financial distress and enhance their contribution to inclusive growth. The research is based on a reflective stance by relying on secondary literature, using the methods of comparative and systematic data analysis. The sources of data are the doctrine, legal acts, reports, and working documents of various international and regional organisations such as the World Bank, UNCITRAL, OECD, International Monetary Fund (IMF), EU, and others, related to the effectiveness of the insolvency law, the methodology of its evaluation, the heterogeneity of business, and the perspectives of small businesses.

The paper is structured as follows: first, we will discuss the objectives of insolvency laws. Then, we will analyse the specific characteristics of small businesses and check if they provide for a specific treatment when designing effective insolvency frameworks. The final chapter provides insights on the most influential international standards, focusing on an evaluation of the effectiveness of insolvency frameworks (World Bank, UNCITRAL, OECD, IMF, EU), their key design features, relevant indicators, their suitability to respond to the needs of IMSEs, conclusions, and suggestions. 


\section{ENTREPRENEURSHIP AND SUSTAINABILITY ISSUES}

ISSN 2345-0282 (online) http://jssidoi.org/jesi/

2020 Volume 8 Number 2 (December)

http://doi.org/10.9770/jesi.2020.8.2(23)

\section{The unique challenges faced by IMSEs in situations of financial distress in comparison to medium sized or large firms}

Analyses of contemporary theories on the objectives of insolvency law (Finch, 1997; Azmi \& Razak, 2013) show that the interests and needs of the debtor should be taken into account. Therefore, one of the key policy choices to be made when designing an insolvency framework relates to how to balance the objectives to provide the debtor protection and creditor recovery against each other (International Monetary Fund [IMF], 1999).

Currently, the literature and policy papers evidence a consensus that to be effective, insolvency frameworks should be accessible to distressed firms and facilitate exit in a predictable and expedient manner. More specifically, they should: i) incentivize the restructuring of viable firms and the liquidation of non-viable ones at low cost in order to maximise the total value of proceeds to be distributed between creditors, shareholders, employees, and other stakeholders; ii) balance the interests of the parties involved to ensure an equitable resolution without discouraging future risk-taking by investors and entrepreneurs; and iii) provide for a timely resolution of insolvency (McGowan \& Andrews, 2016).

While the objectives of insolvency regimes are well-established, there is less consensus on their optimal design (OECD, 2018a). Modern insolvency systems typically have been designed with debtors as larger enterprises in mind (Mokal et al., 2018; The World Bank, 2017). In this chapter, we will analyse if the frameworks and standards that have been developed in, and for, medium-sized or large firms are suitable to be applied to small businesses as well. We will consider whether we might add to this list of objectives an additional one: an effective insolvency framework should respond to the specific needs of financially distressed small businesses.

The first difficulty encountered when conducting research related to small businesses is the apparent lack of a consistent or universally accepted definition of the term small business. The definitions and concepts used for identifying small businesses vary significantly among countries at the regional (e.g., EU level) and international level. It is observed that, in most countries, it is an accepted practice to make use of quantitative criteria when defining a small business enterprise (Mokal et al., 2018; Okyere, 2017). The examples of quantitative criteria in defining a small business are: the number of employees; the sales volume; the value of assets; and the market share (Ardic, Mylenko, \& Saltane, 2011). For example, in the EU a small business is defined as a business with less than 50 employees but also an annual turnover of below $€ 10$ million (EU, 2003).

Despite the variations in applying different measurements, there is a common consensus that the category of small business encompasses the following sub-categories: individual entrepreneurs, micro, and small enterprises (IMSEs).

For the purposes of this paper, we will not rely strictly on the quantitative but rather on the qualitative criteria when defining IMSEs - in other words we will check which shared specific characteristics distinguish them from medium sized and large firms and cause unique challenges in situations of financial distress.

The three main unique characteristics of IMSEs most closely linked with the specific challenges they encounter in insolvency can be distinguished as follows:

1) The first specific characteristic of IMSEs is the blurred distinction between the assets and liabilities of the business and those of the owner. 


\section{ENTREPRENEURSHIP AND SUSTAINABILITY ISSUES}

ISSN 2345-0282 (online) http://jssidoi.org/jesi/

2020 Volume 8 Number 2 (December)

http://doi.org/10.9770/jesi.2020.8.2(23)

In contrast to medium-sized or larger firms, in the majority of cases IMSEs are unincorporated, meaning that the debts of the business are personal liabilities of the owner. Even in cases were IMSEs may have a limited liability form, the personal and business debts of micro and small enterprises are often intertwined. This is because lenders that make loans to small enterprises often require the owner to personally guarantee the debt and/or allow the lender to take a lien on the owner's house (Ortiz-Molina \& Penas, 2007; Berkowitz \& White, 2004; Djankov, Hart, McLiesh, \& Shleifer, 2008). These guarantees and liens abolish the legal distinction between the corporation and its owner for the purposes of the particular loan, and as it is rightly pointed out act as an equivalent to "contracting out" the limited liability protection (Cumming, 2012).

As recognized in the literature and EU reports (Bergthaler et al., 2015; European Commission, 2013), the complex, lengthy, and rigid procedures, required expertise, and high costs of insolvency often fail to adequately meet the needs of micro and small business which are also owned and operated by families who have pledged their personal assets for business credit. In other words, the limited liability of the firm no longer applies to this particular credit (Cirmizi et al., 2010). Another related issue is that there may be no clearly established ownership of key commercial assets (such as tools or other essential equipment). It is not unusual for owners to use personal assets for business purposes and business assets for personal or family needs (UNCITRAL, 2020). The closely linked consequence of these characteristics is that in case of default bankruptcy, the entrepreneur will often face personal as well as corporate insolvency (Cirmizi et al., 2010; Cumming, 2012), and if there is no sound personal insolvency regime then the business debts stay with the debtor for an undefined future period. This is stressed in the literature, showing that while the personal guarantee of a firm's owner might encourage a level of financial discipline, in countries without a personal bankruptcy framework a single business failure could doom an owner to a lifetime of outstanding debt (Uttamchandani \& Menezes, 2010) and effectively prevent them from reentering the market as a seasoned entrepreneur (Armour \& Cumming, 2005).

What challenge does this cause in an insolvency situation? Existing standard business insolvency regimes usually restrict insolvency proceedings to the business debts of a distinct business entity, and do not comprehensively address the intermingled business and personal debts usually involved in the insolvency of IMSEs. As pointed out by the international experts, individual entrepreneurs may be treated as individual defaulters and be subject to personal insolvency frameworks where such frameworks exist. The latter may not provide temporary protection from creditors, nor allow for debt restructuring procedures and discharge. Where discharge is available for individual entrepreneurs, a long waiting period before discharge may apply, leaving full personal liability for many years after the liquidation of the business. Heavy penalties, including limitations on freedom of movement and other personal restrictions, may also apply (UNCITRAL, 2020). The results of empirical research show that the lack of a fresh start with restrictions on the rights of debtors and a lack of protection of their personal assets are associated with both a lower likelihood of being engaged in a start-up and a lower likelihood of high aspirations towards entrepreneurship in particular (Estrin, Mickiewicz, \& Rebmann, 2017).

So, this question of blurring between assets and liability is the main issue to be addressed by insolvency framework aiming to include the perspective of the small business and construct a regime that would effectively handle the situation of the distressed small business.

2) The second specific characteristic of IMSEs is the overlap of ownership, control, and management functions.

The separation between the ownership and the management of IMSEs is blurred in contrast with larger firms with professional management bodies. This feature affects access to insolvency proceedings. Many IMSEs have a centralised management model in which ownership, control, and management overlap (usually within a family) (UNCITRAL, 2020). This causes challenges in times of financial distress because small entrepreneurs fear the 


\section{ENTREPRENEURSHIP AND SUSTAINABILITY ISSUES}

ISSN 2345-0282 (online) http://jssidoi.org/jesi/

2020 Volume 8 Number 2 (December)

http://doi.org/10.9770/jesi.2020.8.2(23)

risk of losing control over their business. Empirical research shows that limitations on the entrepreneurs' control over the firm in insolvency proceedings, such as an automatic stay on secured assets and the mandatory removal of management, are associated with a lower likelihood of individuals entering high-aspiration entrepreneurship, which suggests that such provisions should be avoided (Estrin et al., 2016). An owner may also hide a financial crisis out of fear of damaging a good commercial name, relationships with employees, suppliers, and the market, or disrupting existing lines of credit (UNCITRAL, 2020). IMSEs are most often managed by the owner and not a professional manager in contrast to larger enterprises, and may not have the financial information required for an application to commence insolvency proceedings. Because of these features, IMSEs encounter specific difficulties in financial distress, which their bigger counterparties would not usually face.

3) The third specific characteristic of IMSEs is the lack of assets in situations of financial difficulty, and their related challenges due to limited access to insolvency in general, and to restructuring specifically.

Given that most IMSEs' lending is secured by real estate or a personal guarantee, banks have a strong incentive in the event of a loan default to enforce the guarantee or initiate foreclosure to realize the security and collect proceeds (Bergthaler et al., 2015). Unencumbered assets of IMSEs are usually of little to no value for distribution to unsecured creditors. As a result, those creditors may not be willing to invest the time and resources for the resolution of IMSEs' financial difficulties, because the costs of their participation in those efforts may outweigh the returns. Hold-outs by secured creditors and the disengagement of unsecured creditors jeopardise the chances of successful debt restructuring negotiations and the reorganization of viable IMSEs, leaving liquidation as the only option (The World Bank, 2017). Additionally, due to the lack of (sufficient) funds in the insolvency estate, IMSEs may be ineligible to apply for insolvency in some jurisdictions, or insolvency proceedings may be terminated after their commencement in other jurisdictions (UNCITRAL, 2020). Burdened by unresolved financial difficulties and old debt, IMSEs may be discouraged from taking new risks, become trapped in a cycle of debt, or be driven to the informal sector of the economy (Mokal et al., 2018).

In can be concluded that the traditional assumption among insolvency policy makers for a long time has been that small businesses usually act as larger businesses, only on a smaller scale. We have showed that the size and nature of small businesses distinguishes them from their larger counterparts, creates special challenges in times of financial distress, and requires, inter alia, some very different approaches to insolvency policy.

In order to be effective, insolvency frameworks should address the specific needs of financially distressed small business throughout the entire insolvency framework, focusing on specific points where: access can be improved and made less costly; the question of intermingled assets, liability, and a fresh start will be dealt with; and where IMSEs can be encouraged to seek early advice on how to address their financial difficulties.

\section{Do existing international standards on the effectiveness of insolvency frameworks take into account the specifics of IMSE insolvency?}

\subsection{The international standards on effectiveness of insolvency frameworks - general considerations}

Determining the effectiveness of an insolvency system requires the evaluation of both quantitative and qualitative elements. As insolvency systems seek to achieve complex objectives, the characteristics and the volume of data required to assess their effectiveness can be significant. In addition, there are features of the system that need to be assessed qualitatively. For this reason, the analysis of insolvency systems relies on the interplay of standards, indicators, and data (Garrido et al., 2019). 


\section{ENTREPRENEURSHIP AND SUSTAINABILITY ISSUES}

ISSN 2345-0282 (online) http://jssidoi.org/jesi/

2020 Volume 8 Number 2 (December)

http://doi.org/10.9770/jesi.2020.8.2(23)

In this chapter, we will verify whether the existent international initiatives and instruments that provide guidelines for countries wishing to assess the effectiveness of their current insolvency frameworks, or wishing to steer their reforms towards designing well-functioning insolvency regimes, take into account the specific needs of IMSEs.

For many years, scholars and experts have sought to describe the best framework for insolvency. While there is no universal model or blueprint for optimal insolvency systems worldwide, there are several important standards elaborated on at the international level that reflect best practices endorsed by the international community and underlie what constitutes a sound insolvency regime. These standards represent the consensus of international bodies on the core features of legal or regulatory systems. The two primary internationally recognized benchmarks jointly acknowledged as international standards for insolvency regimes are The World Bank's "Principles for Effective Insolvency and Creditor Regimes" (The World Bank, 2016) and the UNCITRAL's "Legislative Guide on Insolvency Law" (UNCITRAL 2004-2013; Consolo, Malfa, \& Pierluigi, 2018), based on which the World Bank has built the Resolving Insolvency indicator in its most famous product: Ease of Doing Business rankings. The UNCITRAL itself does not provide for specific evaluation criteria and indicators, but the World Bank relies on its research when creating and refining the system of Resolving Insolvency indicators.

Additionally, some other major international players have also provided policy recommendations towards reforms that target insolvency frameworks: the IMF report of 1999 discussed the major policy choices to be addressed by countries when designing insolvency systems (IMF, 1999); OECD compiled a new database on insolvency framework reforms with the 13 OECD indicators of insolvency frameworks (OECD, 2018b); and the EU adopted the new Directive on restructuring and insolvency 2019/1023, which aims at achieving common standards on early restructuring across EU Member States (Directive 2019/1023, 2019).

Next, we will more closely review whether these initiatives take into account the specific characteristics of IMSEs when constructing their guidelines on the evaluation of the effectiveness of insolvency framework.

\subsection{The World Bank Principles and Resolving Insolvency indicators system}

One of the main data sources on insolvency frameworks is the World Bank's Ease of Doing Business index with its specific Resolving Insolvency indicator that not only provides a snapshot of a country's relative position, but also monitors its evolution from one year to the next and allows for an evaluation of the level of achievement.

Even though the Ease of Doing Business Index is formally a non-coercive reporting exercise, and may not always accurately reflect appropriate regulation, its existence has influenced governments around the world to change their economic and regulatory policies. By benchmarking, and especially by ranking, the World Bank intentionally exerts competitive social pressure on states. Plausible observational evidence demonstrates an average global correlation between publicizing the rankings, bureaucratic adaptations responding to the rankings, and the acceleration of actual policy reforms. One investor survey experiment clearly showed that international investors may also be influenced by a state's Ease of Doing Business rankings (Doshi, Kelly, \& Simmons, 2019). The Doing Business index is often cited in the agendas of legislative powers in justifying insolvency reforms with the aim of improving the country's position in the World Bank doing business ranking (e.g., India, Lithuania, Portugal, Yemen, Russia, and many others as seen from the World Bank Group reports). This ranking focuses on regulatory issues and their importance for growth. The close relationship between improving the legislative framework and growth underpins an important set of developments that has been repeated since the beginning of this century. The seminal work by Djankov, McLiesh, and Ramalho (2006) confirms this association (Estevao, Lopes, Panela, \& Soares, 2020).

The Doing Business Index, launched in 2002, aspires to provide evidence-based objective measures of regulations applied to small and medium enterprises through their life cycle. As the Doing Business report explains in its own 


\section{ENTREPRENEURSHIP AND SUSTAINABILITY ISSUES}

ISSN 2345-0282 (online) http://jssidoi.org/jesi/

2020 Volume 8 Number 2 (December)

http://doi.org/10.9770/jesi.2020.8.2(23)

description: "By gathering and analysing comprehensive quantitative data to compare business regulation environments across economies and over time, Doing Business encourages countries to compete towards more efficient regulation; offers measurable benchmarks for reform" (Žylius \& Basheka, 2014; website of Doing Business: https://www.doingbusiness.org/en/doingbusiness). The Doing Business Resolving Insolvency indicators aim at measuring the efficiency and quality of insolvency frameworks around the world. These indicators are not static, and the evaluation system is evolving with each evaluation period.

At the beginning the Resolving Insolvency indicators focused only on outcome-based indicators, capturing the efficiency of insolvency proceedings through the set of recovery rate indicators: the time, cost, and outcome of insolvency proceedings, and how much creditors would recover at the end (i.e., the recovery rate). In 2015, Doing Business introduced an important change in the methodology of indicators for Resolving Insolvency. Besides measuring the recovery rate, it now also tests whether each economy has adopted internationally recognized good practices in the area of insolvency. A new indicator, the strength of insolvency framework index, measures good practices in accordance with the principles developed by the World Bank and the UNCITRAL - the World Bank's "Principles for Effective Insolvency and Creditor/Debtor Regimes" and UNCITRAL's "Legislative Guide on Insolvency Law".

The purpose of the change in the methodology was to provide a more complete and balanced view of the insolvency framework in each economy by addressing both the quality of the law and the efficiency of its implementation - in other words, to focus on the effectiveness instead of just efficiency. Additionally, while the previous methodology focused mainly on secured creditors, the new index widens the reach of the set of Resolving Insolvency indicators to debtors and unsecured creditors (The World Bank, 2014).

So currently, country rankings are based on performance with respect to two equally weighted sub-indicators (50:50):

1) Outcome-based indicators: the recovery rate, based on the time, cost and outcome of insolvency proceedings based on a stylised case study;

2) Strength of Insolvency Framework Index (introduced in 2015), based on four other indices: commencement of proceedings index; management of debtor's assets index; reorganization proceedings index; and creditor participation index.

In order to answer if the needs of IMSEs are being taken into account when evaluating the effectiveness of insolvency regimes applying the Doing business methodology, we need to consider the basis for both of these sub-indicators.

Regarding the methodology of the outcome-based indicators, it is necessary to mention that the case study is used to derive the outcome based (de facto) indicators. This has both advantages and disadvantages. On the positive side, it is a direct attempt to gauge the average time and cost of insolvency proceedings given that survey respondents typically find it difficult to give an exact answer to a general questionnaire without details on the complexity of the individual case (The World Bank, 2014).

From the other side, these answers depend on the situation at hand: general assumptions used as a basis for this methodology are generated based on answers related to one specific situation and one concrete type of subject. So, what are these general assumptions, and do they cover the situation of IMSEs? There are 2 groups of assumptions in the case: 1) assumptions about the business; and 2) assumptions about the case. From the assumptions about the business we can see that the case is based on the example of a firm (a hotel) with more than 200 employees, 50 suppliers, and solid assets (real estate), and has a professional general manager and a market value of operating as a going concern, of 100 times income per capita or US\$200,000, whichever is greater (The World Bank, 2014). So, if compared with the specific characteristics of IMSEs as described above, these business assumptions are based on an example which clearly does not reflect the situation of most IMSEs. 


\section{ENTREPRENEURSHIP AND SUSTAINABILITY ISSUES}

ISSN 2345-0282 (online) http://jssidoi.org/jesi/

2020 Volume 8 Number 2 (December)

http://doi.org/10.9770/jesi.2020.8.2(23)

Firstly, it only covers corporate insolvency and therefore the individual entrepreneurs are not covered by it at all. Second, all of these characteristics of the firm are way above the threshold of the micro and small business, and do not reflect their specific characteristics which require different solutions. Namely, IMSEs in most cases are small family businesses with intermingled personal and business assets led by their owner and not a professional manager, while the case example is clearly a medium-sized professionally led enterprise.

Accordingly, the results acquired by using the methodology related to the outcome-based indicators of the World Bank Doing business Resolving Insolvency indicator do not cover the situation of IMSEs, and therefore cannot per se be transferred and applied to the situation of IMSEs, nor to the situation of individual entrepreneurs who are not covered at all, nor to the situations of micro or small businesses.

Regarding the methodology of the Strength of Insolvency Framework Index it needs to be stressed that, after going through all four indices (commencement of proceedings index, management of debtor's assets index, reorganization proceedings index and creditor participation index) and their components, the conclusion could be made that they do not distinguish between various types of debtor's and concern only the general insolvency questions relevant to larger firms (having access to the proceedings, active participation of creditors, etc.). They do not take into account the specific questions relevant to IMSEs, especially the so-called blurred line between the corporate vs. non-corporate distinction of assets and liabilities (see Berkowitz \& White, 2004; Cumming, 2012).

We can conclude that in the current version of the World Bank Resolving Insolvency indicator system based on international good practice there are no guidelines on how to construct an effective insolvency regime that would cover the specific needs of IMSEs.

\subsection{The OECD indicators for evaluating insolvency regimes}

Another influential international organisation that works on establishing evidence-based international standards and finding solutions to a range of social, economic, and environmental challenges is the OECD. For many years, the OECD has developed a variety of indicators that measure the regulatory barriers for starting businesses and competition, allowing for the comparability of results across countries (Koske, Wanner, Bitetti, \& Barbiero, 2015). However, a similar system of indicators tackling the regulatory barriers to the last cycle of a business's life - firm exit, or in other words insolvency - has been absent.

To fill a gap and provide complementary insights to those of the World Bank indicators system, particularly in regard to the identification of detailed policy-level reform needs, in 2018 the OECD designed and constructed a new set of cross-country indicators of insolvency regimes (McGowan \& Andrews, 2018) via its Going for Growth framework. The choice of questions and the quantitative coding of the potential responses to each question were based on the main conclusions of the theoretical and empirical literature on the links between insolvency regimes and economic growth. The report, which formed the basis for the system of indicators, makes reference to the World Bank system, stating that the available cross-country indicators of insolvency regimes (e.g., World Bank Doing Business) have a number of drawbacks which make it difficult to identify the contribution of insolvency regimes to productivity performance (McGowan \& Andrews, 2016). To fill the gaps in the existing indicators, the OECD presented new cross-country policy indicators on the effectiveness of insolvency regimes.

So does this OECD framework take into account the specific characteristic and needs of distressed IMSEs?

The OECD distinguishes 4 groups of factors to be considered when evaluating the effectiveness of insolvency regimes, and the indicators, in contrast to the World Bank Resolving Insolvency system, cover not only corporate but also personal insolvency. 


\section{ENTREPRENEURSHIP AND SUSTAINABILITY ISSUES}

ISSN 2345-0282 (online) http://jssidoi.org/jesi/

2020 Volume 8 Number 2 (December)

http://doi.org/10.9770/jesi.2020.8.2(23)

Specifically, the four main insolvency indicators (divided into 13 sub-indicators) are:

A. Treatment of failed entrepreneurs: in other words, the availability of a fresh start for failed entrepreneurs with respect to two features: time to discharge; and exemptions of their personal assets from insolvency proceedings;

B. Prevention and streamlining: three mechanisms that aid prevention and streamlining: early warning mechanisms, pre-insolvency regimes, and special insolvency procedures for SMEs;

C. Tools related to actual restructuring: five features: the ability of creditors to initiate restructuring, the availability and length of stay on assets, the priority order of claimants (such as government or employees), the treatment ("cram-down") of dissenting creditors, and the incumbent management;

D. other factors, such as: the degree of court involvement, provisions distinguishing between honest and fraudulent bankruptcies, and the rights of employees (OECD, 2018b).

As we see, the OECD indicators already tackle many questions relevant to IMSEs.

The first key dimension is the treatment of failed entrepreneurs, which is of paramount importance for IMSEs.

The most up-to-date research on the association between the effectiveness of insolvency regulations and entrepreneurship (Fu, Wennbertg, \& Falkenhall, 2020), along with cross-country evidence compiled in the OECD Going for Growth interim report (2018), suggests that in particular a lengthy time to discharge can discourage entrepreneurship. The availability of a "fresh start" has been found to foster the growth of productivity via higher incentives for entrepreneurship and experimentation by: i) increasing firm entry (Cumming, 2012); ii) providing failed entrepreneurs with a second chance to apply their experience and lessons learnt to ensure the growth of their new businesses (Burchell \& Hughes, 2006); and iii) attracting better quality entrepreneurs - i.e., individuals with higher observed human capital (Eberhart, Eesley, \& Eisenhardt, 2016).

The OECD indicator assumes that a lengthier time to discharge is detrimental to the growth of productivity, and hence is given a higher ("worse") value. Threshold values of one and three years are adopted for scoring, with the worst score given to a time to discharge above three years. This is also in line with the EU position of limiting discharge periods in the EU to a maximum of three years for honest entrepreneurs.

The second important position linked with IMSEs can be found under the sub-indicators of the indicator "Prevention and streamlining features", namely "Special insolvency procedures for SMEs". On the one hand, this calls for the specific forms of business to be taken into account, which is good for IMSEs, but conversely this subindicator does not distinguish between IMSEs and medium-sized enterprises that, as we previously clarified, are very different from small businesses. The indicator gives a score only for the existence of special insolvency procedures for SMEs, and does not give any insights into how insolvency framework should be designed in order to take into account the specific characteristics and needs of IMSEs.

Under the third indicator of "Restructuring tools", the OECD summarises the general principles related to sound restructuring regimes (such as the possibility for creditors to initiate restructuring and the possibility of management not to be dismissed during restructuring, which is important for IMSEs as well as for all other forms of business) and does not indicate any specifics related to IMSEs. For example, often in the literature the question of the impeded access of IMSEs to these procedures in general is raised, whether due to the lack of resources to finance such proceedings, to engage an insolvency professional etc. (Mokal et al., 2018).

The fourth indicator "Other design features" again shows some relevance to distressed IMSEs, especially its subindicator related to the degree of court involvement. Court involvement costs and this financial burden could 


\section{ENTREPRENEURSHIP AND SUSTAINABILITY ISSUES}

ISSN 2345-0282 (online) http://jssidoi.org/jesi/

2020 Volume 8 Number 2 (December)

http://doi.org/10.9770/jesi.2020.8.2(23)

impede access of IMSEs to insolvency procedures, due to a lack of assets to cover the associated fixed costs (Bergthaler et al., 2015).

In conclusion, the OECD indicators partially take into account the specifics of the IMSEs, but provide no coherent system for the elements to be included into insolvency framework in order to have an effective insolvency regime for IMSEs. Still, this is currently the most important available tool, giving at least some initial guidance to countries on how to construct effective insolvency framework that can respond to the specific needs of IMSEs. These indicators also allow for cross-country comparisons of certain features of the design of insolvency regimes regarding how they treat financially distressed IMSEs, and give future insights for policy reforms in this area.

\subsection{Other standards and initiatives}

As already mentioned, the IMF also targeted the issue of effective insolvency framework with its "Guidelines for Orderly and Effective Insolvency Procedures" (IMF, 1999), which was primarily concerned with the application of insolvency laws to enterprises rather than individuals. This report did not distinguish between large and small enterprises and, before formulating general guidelines, clearly stated that a number of the issues discussed may only be of particular relevance to a relatively large enterprise that has a number of creditors with divergent interests. Due to the limited scope of this report, we can conclude that there are no guidelines in the IMF report on how to construct an effective insolvency regime that would take into account the specific characteristics and needs of IMSEs.

We can find some general ideas on the importance of IMSEs in its later report from 2015_-"Tackling Small and Medium Sized Enterprise Problem Loans in Europe" (Bergthaler et al., 2015) — which presumed that, based on cross-country experience with distressed small and medium sized enterprises (SMEs), a comprehensive strategy including insolvency reform targeted at SMEs is needed. Insolvency regimes should close the gap with international best practice for rapid pre-pack approvals, "fresh start"/debt discharge, and debtor-in-possession financing. As we have outlined, these proposed solutions address the whole business sector in general but are not specifically tailored for IMSEs.

At the EU level, a number of initiatives were developed targeting the regulatory framework for small businesses, including the Small Business Act 2008 which outlines a set of recommendations based on cross-country experience and good practice, but does not specifically focus on insolvency issues (European Commission, 2008). The most important achievement at the EU level is the new Directive 2019/1023 of the European Parliament and of the Council of 20 June 2019 on preventive restructuring frameworks, on the discharge of debt and disqualifications, and on measures to increase the efficiency of procedures concerning restructuring, insolvency, and discharge of debt, and amending Directive (EU) 2017/1132 (Directive on restructuring and insolvency), which aims at enhancing rescue culture in the EU and encouraging entrepreneurship by avoiding the stigmatization of business failure and providing the opportunity for a second chance. However, its approach was rightly criticized in the literature for not devoting enough attention to micro, small, and medium sized enterprises (and following, not taking into account the specifics of IMSEs), and clearly designing most of its provisions for larger corporations (Madaus, 2017; Mokal et al., 2018). Additionally, the EU constructed the information tool "EU Justice Scoreboard", which aims at helping the EU to achieve more effective justice and provides comparable data on the independence, quality, and efficiency of national justice systems. This scoreboard, however, does not focus specifically on insolvency problems and, as is almost self-explanatory, does not provide EU Member States with concrete standards and indicators for the evaluation of the effectiveness of insolvency frameworks in relation to the specifics of IMSEs. 


\section{ENTREPRENEURSHIP AND SUSTAINABILITY ISSUES}

ISSN 2345-0282 (online) http://jssidoi.org/jesi/

2020 Volume 8 Number 2 (December)

http://doi.org/10.9770/jesi.2020.8.2(23)

In conclusion, whilst EU initiatives may have some important implications for IMSEs they are not tailored specifically to IMSEs, and do not provide countries with the standards or indicators of best practice that might enable them to guide reforms aimed at improving the effectiveness of insolvency framework for IMSEs.

The overall conclusion based on the analysis of the existing international initiatives and instruments is that currently there is no comprehensive international guidance which could stimulate and steer countries to improve the effectiveness of their insolvency frameworks in a way that would respond to the needs of the majority of businesses - IMSEs.

There is a need to create a more all-encompassing framework for the evaluation of the effectiveness of regimes of insolvency law applicable specifically to IMSEs. The international community is becoming aware of this, and has already initiated some important steps in order to tackle this problem. The most important work currently in progress is the UNCITRAL work on a "Draft Text to Simplify Insolvency Regime Proceedings" (UNCITRAL, 2020), which specifically targets the needs of financially distressed small business. From the agendas of the World Bank, it can also be seen that a new objective for its Working Groups to prepare a joint standard setter together with UNCITRAL in the area of insolvency for small businesses has been introduced (The World Bank, 2017). If it succeeds with outlining a specific set of indicators related to small businesses, then this would be a major reform stimulus for many countries aiming at improving the effectiveness of insolvency frameworks for IMSEe.

\section{Conclusions}

This research argues that one of the key objectives of an effective insolvency framework should be to provide solutions on specific issues arising from the insolvencies of IMSEs, such as the blurred distinction between the assets and liabilities of the business and those of the owner, the overlap of ownership, control, and management functions, concerns over stigmatization, resource poverty, and the disengagement of creditors.

The analysis of the existing international guidelines that deal with the evaluation of the effectiveness of insolvency frameworks shows that current good practice guidelines and indicators either do not cover issues that are important for IMSEs at all or are tackling only some of them in a more general manner. Specifically, countries aiming at improving their World Bank Doing Business ranking in relation to the Resolving Insolvency indicator should be aware of its current limitations regarding the specific needs of IMSEs in times of financial distress. The OECD indicators of insolvency regimes are currently the most suitable tool for providing some initial guidance on how to construct effective an insolvency framework that adequately addresses at least some of the specific needs of IMSEs.

Despite these positive steps in initiating the reforms aimed at targeting the needs of financially distressed IMSEs, there is a need for a more comprehensive approach toward IMSEs in financial distress which would stimulate and steer countries to improve the effectiveness of their insolvency frameworks in a way which would respond to the needs of the majority of businesses: IMSEs, and to encourage entrepreneurship as a consequence. 


\section{ENTREPRENEURSHIP AND SUSTAINABILITY ISSUES}

ISSN 2345-0282 (online) http://jssidoi.org/jesi/

2020 Volume 8 Number 2 (December)

http://doi.org/10.9770/jesi.2020.8.2(23)

\section{References}

Ardic, O. P., Mylenko, N., \& Saltane, V. (2011). Small and medium enterprises: A cross-country analysis with a new data set. World Bank Policy Research Working Paper No. 5538. https://doi.org/10.1596/1813-9450-5538

Armour, J., \& Cumming, D. J. (2005). Bankruptcy law and entrepreneurship. ESRC Centre for Business Research Working Paper No. 300. Retrieved from https://www.cbr.cam.ac.uk/fileadmin/user_upload/centre-for-business-research/downloads/working-papers/wp300.pdf

Azmi, R., \& Abd Razak, A. (2013). Theories, objectives and principles of corporate insolvency law: a comparative study between Malaysia and UK. Proceedings of the 3rd International Conference on Management, 10-11 June 2013, Hydro Hotel, Penang, Malaysia (pp. 667679). paper. Retrieved from http://repo.uum.edu.my/12310/

Bergthaler, W., Kang, K., Liu, Y., \& Monaghan, D. (2015). Tackling small and medium enterprise problem loans in Europe. International Monetary Fund. Retrieved from https://www.imf.org/external/pubs/ft/sdn/2015/sdn1504.pdf

Berkowitz, J., \& White, M. (2004). Bankruptcy and small firms' access to credit. RAND Journal of Economics, 35(1), 69-84. Retrieved from https://econweb.ucsd.edu/ miwhite/rje.spring04.berkowitz.pdf

Burchell, B., \& A. Hughes (2006). The stigma of failure: An international comparison of failure tolerance and second chancing. University of Cambridge Centre for Business Research Working Paper No. 334. Retrieved from https://www.cbr.cam.ac.uk/fileadmin/user_upload/centre-for-business-research/downloads/working-papers/wp334.pdf

Consolo, A., Malfa, F., \& Pierluigi, B. (2018). Insolvency frameworks and private debt: an empirical investigation. ECB Working Paper No. 2189. Retrieved from SSRN: https://ssrn.com/abstract $=3275147$

Cumming, D. (2012). Measuring the effect of bankruptcy laws on entrepreneurship across countries. Journal of Entrepreneurial Finance, 16(1), Article 4. Retrieved from https://digitalcommons.pepperdine.edu/cgi/viewcontent.cgi?article=1007\&context=jef

Cirmizi, E., Klapper, L., \& Uttamchandani, M. (2010). The challenges of bankruptcy reform. World Bank Policy Research Working Paper No. 5448. Retrieved from https://ssrn.com/abstract=1694337

Directive 2019/1023 of the European Parliament and of the Council of 20 June 2019 on preventive restructuring frameworks, on discharge of debt and disqualifications, and on measures to increase the efficiency of procedures concerning restructuring, insolvency and discharge of debt, and amending Directive (EU) 2017/1132 (Directive on restructuring and insolvency). OJ L 172, 18-55.

Djankov, S., Hart, O., McLiesh, C., \& Shleifer, A. (2008). Debt enforcement around the world. Journal of Political Economy, 116(6), 1105-1149. Retrieved from https://www.doingbusiness.org/content/dam/doingBusiness/media/Methodology/Supporting-Papers/DBMethodology-Debt-Enforcement-around-the-World.pdf

Djankov, S., McLiesh, C., \& Ramalho, R. M. (2006). Regulation and growth. Economic Letters, 92(3), 395-401. https://doi.org/10.1016/j.econlet.2006.03.021

Doshi, R., Kelly, J. G., \& Simmons, B. A. (2019). The power of ranking: The Ease of Doing Business Indicator and Global Regulatory Behavior. International Organization, 73(3), 611-643. https://doi.org/10.1017/S0020818319000158

Eberhart, R., Eesley, C., \& Eisenhardt, K. (2016). Failure is an option: Failure barriers and new firm performance. Rock Centre for Corporate Governance at Stanford University Working Paper No. 111. Retrieved from http://ssrn.com/abstract=1982819

Estevao, J., Lopes, J. D., Panela, D., \& Soares, J. M. (2020). The Doing Business ranking and the GDP. A qualitative study. Journal of Business Research, 115, 435-442. https://doi.org/10.1016/j.jbusres.2019.11.067

Estrin, S., Mickiewicz, T., \& Rebmann, A. (2017). Prospect theory and the effects of bankruptcy laws on entrepreneurial aspirations. Small Business Economics, 48, 977-997. https://doi.org/10.1007/s11187-016-9810-1

European Commission. (2000). European Charter for Small Enterprises. Retrieved from https://ec.europa.eu/growth/content/europeancharter-small-enterprises-0_en 


\section{ENTREPRENEURSHIP AND SUSTAINABILITY ISSUES}

ISSN 2345-0282 (online) http://jssidoi.org/jesi/ 2020 Volume 8 Number 2 (December) http://doi.org/10.9770/jesi.2020.8.2(23)

European Commission (2003). Recommendation of 6 May 2003 concerning the definition of micro, small and medium-sized enterprises. $\mathrm{C}(2003) 1422)$. OJ L 124, 36-41.

European Commission. (2008). Communication from the Commission to the Council, the European Parliament, the European Economic and Social Committee and the Committee of the Regions - "Think Small First" - A "Small Business Act" for Europe \{SEC(2008) 2101\} \{SEC(2008) 2102\} COM/2008/0394 final. Retrieved from https://eur-lex.europa.eu/legal-content/EN/TXT/?uri=CELEX:52008DC0394

European Commission. (2012). Communication from the Commission to the European Parliament, the Council, the European economic and social committee and the Committee of the regions. Entrepreneurship 2020 Action Plan. Reigniting the entrepreneurial spirit in Europe. COM/2012/0795 final. Retrieved from https://eur-lex.europa.eu/legal-content/EN/TXT/?uri=celex:52012DC0795

European Commission. (2013). Finance for growth. Report of the High Level Expert Group on SME and infrastructure financing. Retrieved from http://www.cica.net/wp-content/uploads/2015/11/hleg report 2013.pdf

European Commission. (2019). Communication from the Commission to the European Parliament, the Council, the European central bank, the European economic and social committee, the Committee of the regions and the European investment bank. Annual sustainable growth $\quad$ strategy 2020 . COM/2019/650 final. Retrieved from https://eur-lex.europa.eu/legalcontent/EN/TXT/?qid=1578392227719\&uri=CELEX\%3A52019DC0650

European Commission. (2020). Communication from the Commission to the European Parliament, the Council, the European economic and social committee and the Committee of the regions. An SME Strategy for a sustainable and digital Europe COM/2020/103 final. Retrieved from https://eur-lex.europa.eu/legal-content/EN/TXT/?uri=COM\%3A2020\%3A103\%3AFIN

EU Directorate-General for Communication. (2015). Flash Eurobarometer 354: Entrepreneurship in the EU and beyond. Retrieved from EU Open Data Portal http://data.europa.eu/88u/dataset/S1024_354

Finch, V. (1997). The measures of insolvency law. Oxford Journal of Legal Studies, 17(2), 227-251. https://doi.org/10.1093/ojls/17.2.227

Fu, K., Wennbertg, K., \& Falkenhall, B. (2020). Productive entrepreneurship and the effectiveness of insolvency legislation: a crosscountry study. Small Business Economics, 54, 383-404. https://doi.org/10.1007/s11187-018-0040-6

Garrido, J., Bergthaler, W., DeLong, C., Johnson, J., Rasekh, A., Rosha, A., \& Stetsenko N. (2019). The use of data in assessing and designing insolvency systems. IMF Working Paper No. 19/27. Retrieved from https://www.imf.org/en/Publications/WP/Issues/2019/02/04/The-Use-of-Data-in-Assessing-and-Designing-Insolvency-Systems-46549

International Monetary Fund. (1999). Orderly \& Effective Insolvency Procedures. Key Issues. Retrieved from https://www.imf.org/external/pubs/ft/orderly/index.htm

Klapper, L., Laeven, L., \& Rajan, R. (2006). Entry regulation as a barrier to entrepreneurship. Journal of Financial Economics, 82(3), 591629. https://doi.org/10.1016/j.jfineco.2005.09.006

Koske, I., Wanner, I., Bitetti, R., \& Barbiero, O. (2015). The 2013 update of the OECD's database on product market regulation: Policy insights for OECD and non-OECD countries. OECD Economics Department Working Papers No. 1200. https://doi.org/10.1787/5js3f5d3n2vl-en

Madaus, S. (2017). The Impact on SMEs of the Proposal of Preventive Restructuring, Second Chance and Improvement Measures. European Parliament, Directorate General for Internal Policies, Policy Department for Citizens' Rights and Constitutional Affairs. Retrieved from https://www.europarl.europa.eu/thinktank/en/document.html?reference=IPOL_IDA(2017)583151

McGowan, M. A., \& Andrews, D. (2016). Insolvency regimes and productivity growth. OECD Economics Department Working Papers No. 1309. https://doi.org/10.1787/5jlv2jqhxgq6-en

McGowan, M. A., \& Andrews, D. (2018). Design of insolvency regimes across countries. OECD Economics Department Working Papers No. $1504 . \quad$ Retrieved from http://www.oecd.org/officialdocuments/publicdisplaydocumentpdf/?cote=ECO/WKP(2018)52\&docLanguage=En

Mokal, R., Davis, R., Mazzoni, A., Mevorach, I., Romaine, B., Sarra, J., Tirado, I., \& Madaus, S. (2018). Micro, small and medium enterprise insolvency. A modular approach. Oxford: Oxford University Press. https://doi.org/10.1093/oso/9780198799931.001.0001 


\section{ENTREPRENEURSHIP AND SUSTAINABILITY ISSUES}

ISSN 2345-0282 (online) http://jssidoi.org/jesi/

2020 Volume 8 Number 2 (December)

http://doi.org/10.9770/jesi.2020.8.2(23)

Nickell, J. S (1996). Competition and corporate performance. Journal of Political Economy, 104(4), 724-746. https://doi.org/10.1086/262040

OECD (2018a). Strengthening SMEs and entrepreneurship for productivity and inclusive growth: Key issues paper. Prepared for OECD SME Ministerial Conference, 22-23 February 2018, Mexico City. Retrieved from https://ec.europa.eu/transparency/regexpert/index.cfm?do=groupDetail.groupMeetingDoc\&docid=12471

OECD (2018b). Policies for productivity: the design of insolvency regimes across countries. In OECD, Economic policy reforms 2018: Going for growth interim report (pp. 87-109). Paris: OECD Publishing. Retrieved from http://www.oecd.org/economy/growth/policies-forproductivity-the-design-of-insolvency-regimes-across-countries-2018-going-for-growth.pdf

Okyere, F. (2017). Relationship between entrepreneurship and small, medium and micro enterprises (SMMEs): A literature review. The International Journal of Business \& Management, 5(9), $159-163 . \quad$ Retrieved from http://internationaljournalcorner.com/index.php/theijbm/article/view/125039

Ortiz-Molina, H., \& Penas, M.F. (2007). Lending to small businesses: the role of loan maturity in addressing information problems. Small Business Economics, 30, 361-383. https://doi.org/10.1007/s11187-007-9053-2

The World Bank. (2014). Resolving Insolvency: Measuring the strength of insolvency laws. In Doing Business 2015: Going Beyond Efficiency (pp. 96-101). https://doi.org/10.1596/978-1-4648-0351-2_Resolving_Insolvency

The World Bank. (2016). Principles and guidelines for effective insolvency and creditor rights systems. Washington, D.C.: International Bank for Reconstruction and Development; The World Bank Group. Retrieved from http://pubdocs.worldbank.org/en/919511468425523509/ICR-Principles-Insolvency-Creditor-Debtor-Regimes-2016.pdf

The World Bank (2017). Report on the treatment of MSME insolvency (English). Washington, D.C.: World Bank Group. Retrieved from http://documents.worldbank.org/curated/en/973331494264489956/Report-on-the-treatment-of-MSME-insolvency

UNCITRAL. (2004-2013). Legislative Guide on Insolvency Law (Parts one and two, 25 June 2004; part three, 1 July 2010 ; part four, 18 July 2013). Retrieved from https://uncitral.un.org/en/texts/insolvency/legislativeguides/insolvency law

UNCITRAL. (2020). Draft text on a simplified insolvency regime. Working Group V (Insolvency Law). Fifty-seventh session New York, 11-14 May 2020. Retrieved from https://undocs.org/en/A/CN.9/WG.V/WP.170

United Nations. (2017). Promoting entrepreneurship for sustainable development: a selection of business cases from the EMPREC network. Retrieved from https://unctad.org/en/PublicationsLibrary/diaeed2017d6_en.pdf

Uttamchandani, M., \& Menezes, A. (2010). Freedom to fail: Why small business insolvency regimes are critical for emerging markets. International Corporate Rescue, 7(4). Retrieved from http://www.chasecambria.com/site/journal/article.php?id=488

Žylius, R, \& Basheka, B. C. (2014). Insights on the relevance of World Bank Doing Business reports and the recommendations for improvement. Norway Registers Development AS; Uganda Technology and Management University. Retrieved from https://www.nrd.no/file/repository/resources/insights_on_doing_business_nrd_utamu.pdf 
Salvija MULEVIČIENÉ holds a PhD in law and is currently an associate professor at the Institute of Private Law at the Law School of Mykolas Romeris University, Lithuania. She is also the head of the Justice Research Laboratory at Mykolas Romeris University. Her research interests include European and international insolvency law, comparative law, effectiveness and evaluation of justice systems.

ORCID ID: https://orcid.org/0000-0002-8426-3320

Make your research more visible, join the Twitter account of ENTREPRENEURSHIP AND SUSTAINABILITY ISSUES: @Entrepr69728810

Copyright (C) 2020 by author(s) and VsI Entrepreneurship and Sustainability Center

This work is licensed under the Creative Commons Attribution International License (CC BY).

http://creativecommons.org/licenses/by/4.0/

\section{(c) (7) Open Access}

